\title{
アモルファス金属箔ヘのアルミニウム薄板または箔の電磁圧接
}

\author{
相沢 友勝 ${ }^{* 1}$, 松澤 和夫 ${ }^{* 1}$, 岡川 啓悟 ${ }^{* 1}$, 石橋 正基 $^{* 1}$
}

\section{Magnetic Pulse Welding of Aluminum Sheet or Foil to Amorphous Metal Foil}

\author{
Tomokatsu AIZAWA $^{* 1}$, Kazuo MATSUZAWA ${ }^{* 1}$, Keigo OKAGAWA ${ }^{* 1}$ and Masaki Ishibashi ${ }^{* 1}$ \\ ${ }^{*_{1}}$ Tokyo Metropolitan College of Industrial Technology \\ 1-10-40, Higashi-Ohi, Shinagawa-ku, Tokyo 140-0011, Japan
}

This paper describes a novel welding technique of an aluminum sheet to amorphous metal foil and its experimental results. When a discharge current from a capacitor bank passes through a flat one-turn coil, a magnetic flux is suddenly generated around the coil. Eddy currents are induced in the overlapped aluminum sheet and amorphous foil placed on the coil. The sheet and the foil have a gap between them. Electromagnetic force acts on the sheet and lets the sheet collide and weld to the foil. Similarly, aluminum foil on the aluminum sheet can be welded to the amorphous foil. The foils do not melt. The bank energy required for this welding is less than $1.0 \mathrm{~kJ}$.

Key Words : Amorphous metal foil, Aluminum foil, Impact welding, Magnetic pulse welding, Electromagnetic shield

\section{1. はじめに}

磁気（低周波磁界）に対するシールド（遮蔽）としてアモルファス金属䈃など高透磁率材が，電磁波（高周波 電磁界）に対するシールドとしてアルミニウム（以下アルミ）箔など高導電率材が使用される. 両材料を複合化 することで，シールド性能をより高めることができる(1). シールド用に複合化される金属箔は，一般的に，導電 接続, アース (接地) される.アモルファス金属箔とアルミ簿などの接合（溶接）が必要になる. アモルファス 金属は，非晶質構造を維持したまま固体となった金属であり，加熱すると結晶化が生じ，その特性を発揮できな くなる. このため, 接合時の加熱温度に制限がある.ここでは, アモルファス金属箔へアルミ薄板（または箔） を溶融させずに電磁圧接する原理, 方法とともに実験結果を報告する.

\section{2. 原理・方法}

電磁圧接（溶接）用コイルの概略を図 1 に示す．電流が集中するコイル中央部分に高密度磁束（強い磁界）が 発生する. 絶縁されたコイル上面に, アルミ薄板及びアモルファス箔を図 2 (断面図) のように置く. 両者は, 間隙（0.5 mm）を有して向き合っている. アルミ薄板は直流的にコイルから絶縁分離されているが，交流的には コイルと電磁誘導結合している. コイル, 薄板及びアモルファス簿は, 上下に置かれる固定具で固定される.

コイルに大電流を急激に流すと，電流が集中するコイル中央部分に高密度磁束が発生し，図 2 のようにアルミ 薄板及びアモルファス䈃に交差する．この結果, 薄板及び䈃に渦電流と呼ばれる誘導電流が流れ, これらはジュ 一ル加熱される. 渦電流が流れる薄板には, 上向きの電磁力 $f$ が㗢く. この電磁力でアルミ薄板は, 点線のよう に変形しながら,アモルファス箔へ高速衝突し, コイル中央部分に沿って圧接（シーム溶接）される, 衝突の際, 接合面はクリーニングされる．通電時間が極めて短いので圧接後の温度上昇は少ない.

アルミ箔をアモルファス箔へ圧接することもできる. 圧接前のアルミ薄板（図 2）を絶縁し，この上にアルミ 箔を重ねる．これらを図 2 と同様に配置, 固定し，コイルへ大電流を流せば，アルミ箔だけがアモルファス箔へ 圧接される.アルミ薄板はアルミ箔が溶融するのを防ぐ(2).

"I 東京都立産業技術高等専門学校（广140-0011 東京都品川区東大井 1-10-40）

E-mail: aizawa@mem.iee.or.jp 


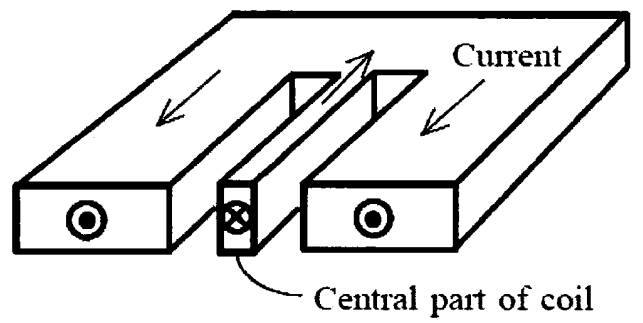

Fig.1 Illustration of coil for welding.

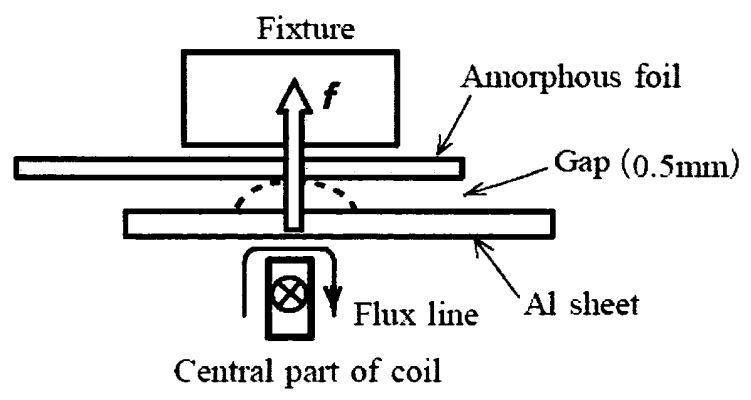

Fig. 2 Principle of welding. Electromagnetic force $f$ acts on $\mathrm{Al}$ sheet and lets $\mathrm{Al}$ sheet collide and weld to amorphous foil.

\section{3. 実験装置}

コイルヘ大電流を急激に流すためコンデンサ放電装置を使用する．コンデンサ電源（容量 $24 \mu \mathrm{F} ）$ を充電し，放 電スイッチを閉じ，コイルへ放電大電流を流す，電源の充電電圧は約 $7 \sim 9 \mathrm{kV}$ ，充電エネルギーは約 $0.6 \sim 0.9 \mathrm{~kJ}$ である. コイルは板厚 $5 \mathrm{~mm}$ のクロム銅製で，コイル中央部分の横幅は $2 \mathrm{~mm}$ である. 中央部分と周辺部分の間 には，絶縁材 (ポリカーボネート) を置く．装置の構成，溶接部分の固定方法については文献 ${ }^{2)} に$ 示す.

磁気シールド用のアモルファス金属䈃（Fe-B-Si 系）は厚さ約 $25 \mu \mathrm{m}$, 電磁シールド用のアルミ薄板（A1050） は厚さ $0.2 \mathrm{~mm}$, アルミ箔は厚さ $20 \mu \mathrm{m}$, これらの横幅は $25 \mathrm{~mm}$ である. 簿及び薄板を図 2 のように間隙 $(0.5 \mathrm{~mm})$ を設けて重ね，固定する．固定具とアモルファス金属箔の間には，必要に応じて薄い衝撃吸収材などを置く.

サーチコイル, オシロスコープなどを用いて圧接用コイルに流れる電流波形などを観測し, 電流值, 磁束密度 などを概算する．また，顕微鏡観察，引張試験により接合状態を，X線回折により結晶状態を調べる，

\section{4. 実験結果}

\section{$4 \cdot 1$ 電流波形及び関係量}

圧接時のコイルには, 振動周期約 $7 \mu \mathrm{s}$ で減衰振動する電流が約 $30 \mu \mathrm{s}$ 流れた. 最大電流値は充電エネルギー0.6 kJ のとき約 $140 \mathrm{kA}$ であり, コイルとアルミ薄板の間に発生する最大磁束密度は約 $26 \mathrm{~T}$ と算出される. このとき, 薄板に加わる最大磁気圧力（電磁力に相当する）は 約 $230 \mathrm{MPa}$, 薄板がアモルファス金属箔へ衝突する速度は約 $300 \mathrm{~m} / \mathrm{s}$ と概算される.

\section{$4 \cdot 2$ 圧接継手の外钼及び接合界面}

アモルファス金属䈃へアルミ薄板（または箔）を電磁圧接した継手の外観例を図 3 に示す．外観中央近くの密 着している部分が縦に端から端まで圧接 (シーム溶接) されている. この長さは材料の幅と等しく $25 \mathrm{~mm}$ である. アモルファス金属箔/アルミ薄板（図 3a）の接合部分には，幅 $5 \mathrm{~mm}$ 程度の変形が見られる.この幅の一部が接 合している.これに対し,アモルファス金属箔/アルミ箔（図 $3 b$ ) の接合部分での変形は比較的に少なく,幅 $2 \mathrm{~mm}$ 程度の変形跡が見られる. 従来, アモルファス金属箔継手の表面に見られた亀裂(3)が，ここでは見られない。

継手を圧接（シーム溶接）方向に垂直に切断，研磨し，顕微鏡観察した接合界面を図 4 に示す．接合部分は, 図 4 (a), (b) のように 2 カ所に生じる. 接合部分 (片側) の長さは, 図 4 (a) で $0.3 \mathrm{~mm}$ 程度, 図 4 (b) で $0.7 \mathrm{~mm}$ 程

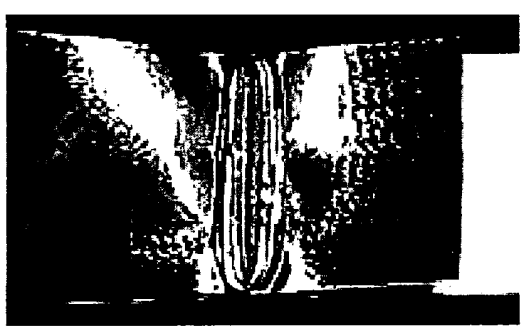

(a) Amorphous (upper) / Al sheet (lower)

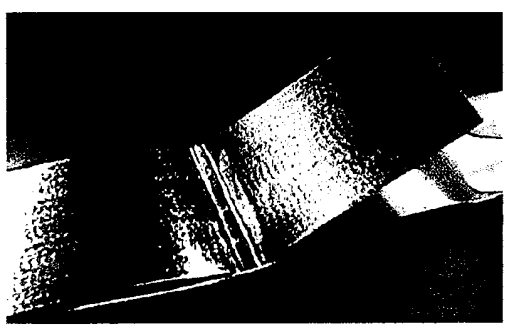

(b) Amorphous (upper) / Al foil (lower)

Fig.3 Appearance of welded joints. Welding length is $25 \mathrm{~mm}$. 


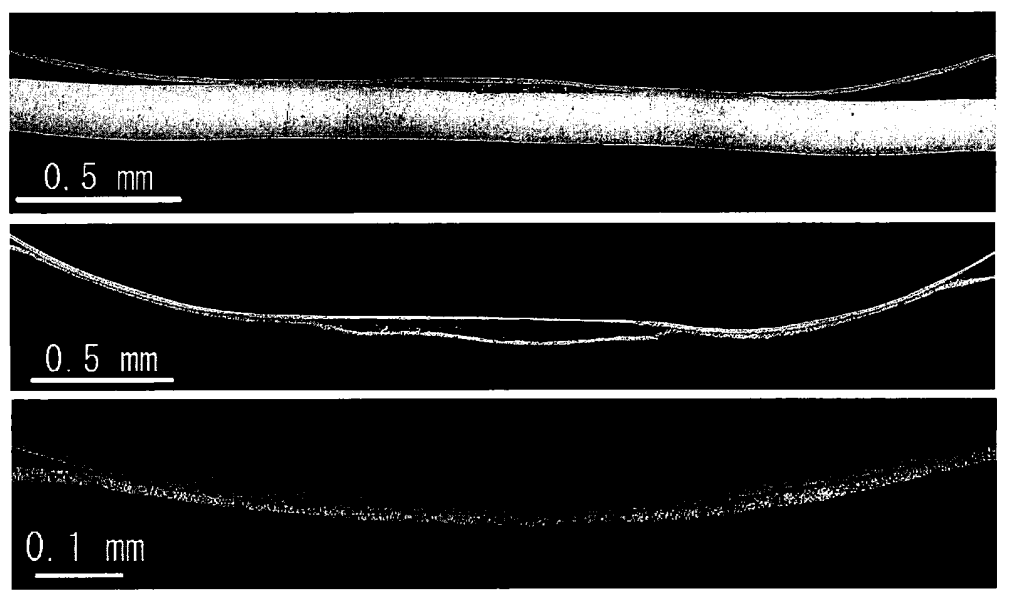

(a) Amorphous (upper) / Al sheet (lower)

(b) Amorphous (upper) / $\mathrm{Al}$ foil (lower)

(c) Amorphous (upper) / $\mathrm{Al}$ foil (lower) Enlarged picture for figure (b) left part

Fig. 4 Micrographs of weld interface of joints. Amorphous foil is $25 \mu \mathrm{m}$ thick, $\mathrm{Al}$ sheet $0.2 \mathrm{~mm}$ thick, Al foil $20 \mu \mathrm{m}$ thick.

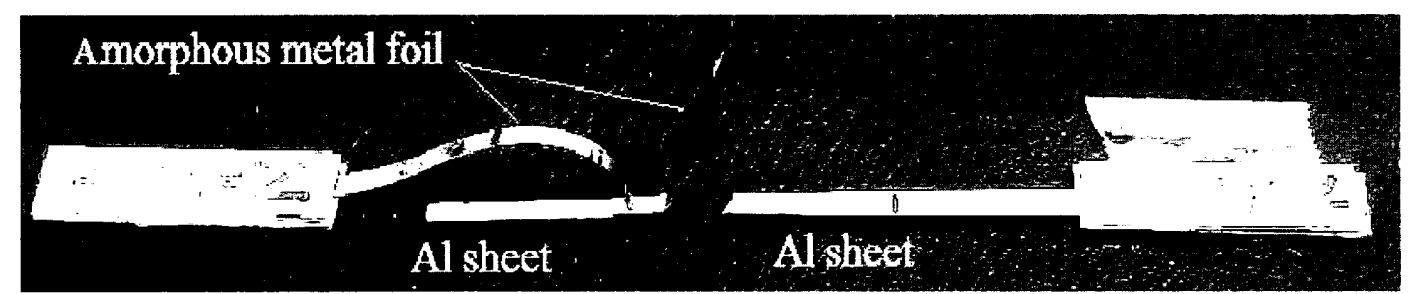

Fig.5 Break example of test specimen after tensile shear test. Specimen of $5 \mathrm{~mm}$ in width was cut out from welded joint.

度である.このように 2 力所で接合する状態は従来の電磁圧接結果と同様である ${ }^{(2),{ }^{(3)} .}$

\section{4・3 引張試験及びX線回折結果}

継手から引張試験片（幅 $5 \mathrm{~mm}$ など）を切り出し, 引張せん断試験した. アモルファス金属箔／アルミ薄板, アモルファス金属箔/アルミ箔の場合ともに，接合部分ははく離せず，アルミ母材で破断する結果が得られた. 破断例を図 5 に示す．アルミ母材が伸びながら，接合部分近くで破断している．アルミ薄板（板厚 $0.2 \mathrm{~mm} ）$ 破断 時の引張強度は 80〜130 MPa，アルミ箔（板厚 $20 \mu \mathrm{m}$ ）の場合 70〜160 MPa であった.

X線回折の結果では, 加熱により結晶化させたアモルファス金属䇴の回折パターンとの比較で, 電磁圧接 後のアモルファス金属箔が非晶質構造を維持していることが分かった．詳細については，本講演で述べる.

\section{5. まとめ}

アモルファス金属箔ヘアルミ薄板（または箔）を電磁圧接する原理，方法及び実験結果を報告した．接合部分 は, 断面 2 力所に生じ, コイル中央部分に沿って 2 本線状にシーム溶接された. 引張せん断試験では, アルミ母 材で破断する強度が得られた．アモルファス金属箔は，圧接後も非晶質構造を維持していた．電磁圧接が磁気及 び電磁シールド複合材の接合（溶接）に使えるようにしたい.

\section{文献}

（1）電子情報通信学会編, “電子システムの電磁ノイズ 一評価と対策”, オーム社, (2012), pp.151-161,

（2）相沢友勝, “電気・電子部品を電磁圧接するための基礎実験”, 電子情報通信学会技術研究報告, Vol.112,No.370 (2012), pp.7-12.

（3）相沢友勝, 渡邊満洋, 熊井真次, 米山夏樹, “アモルファス金属箔の電磁圧接”, 溶接学会全国大会講演概要, 78 集, (2006), pp.174-175. 